\title{
Anthropology and Ethnicity: From Herder to Hermeneutics
}

\section{Jack Eller \\ Westwood College of Technology}

For a long time, the central focus of anthropology has been on the study of the so-called traditional societies. However, with the transformation of those societies into "ethnicized" groups within state systems, anthropologists have had to rethink their concepts, theories, and methods. They have had to deal with, among others things, issues of cultural difference, cultural boundaries, and cultural movements. This article looks retrospectively at certain changes that have taken place in anthropology especially with regard to the study of ethnicity.

Anthropology has not generally been considered, by outsiders or by itself, as concerned centrally with ethnicity. As Evans-Pritchard, one of the deans of early anthropology, wrote: "While social anthropologists consider that their subject embraces all human cultures and societies, including our own, 
they have...for the most part given their attention to those of primitive peoples." $i$ But, with the realization that there are no "primitive" peoples and with the transformation of supposedly isolated "traditional" societies into minorities within state systems, the discipline has not only found itself confronted with "ethnicized" groups but has been compelled to rethink its concepts, theories, and methods in ways which are significant and instructive for ethnic studies.

This opportunity to look retrospectively at anthropology traces the course of ethnographic and theoretical encounters with what would come to be called "ethnicity." The major contributors to an "anthropology of ethnicity" are presented, even though they often did not see themselves as engaged in such an effort. Rather, as the field grappled with cultural difference, cultural boundaries, and cultural movements, it found itself inhabiting an "ethnic" landscape. As the qualities-and even the contents-of those cultures changed, anthropology necessarily reflected back upon its own concepts and theories and engaged in a significant re-thinking, especially in regards to what exactly a "society" is, what its relation to "culture" is, and how we should represent it ethnographically. These issues should be and have been important for ethnic studies and speak to the convergence of the social sciences in this crucial domain.

\section{Romantic Nationalism and "Culture Circles"}

Before there were scholars of ethnicity or nationalism, there were ethnic and national phenomena, or better yet, ethnic or nationalist activists; then, as today, "the significance of the ethnic factor in many societies has been forced upon us more by events than by research." One of the first and most influential scholar-activists of what we could call "ethnic consciousness" today is the German nationalist philosopher Johann Herder (1744-1803). Herder believed that the agent of human history is not the species as a whole nor the individual but an intermediate level, the national group or nationality. This is because each national group, he argued, is an "organic unit," a "national organism" with its own unique and natural qualities and genius, its own special culture and language, its 
own national soul. Herder used such phrases as Nationalgeist, Seele des Volks, Geist der Nation, and Geist des Volks to capture this national peculiarity which was, to him, "inexpressible." Being that the "natural and the national were synonomous in Herder's mind"ii he perceived it as the ineffable yet rightful unit of mankind: "Every nationality is one people, having its own national culture as well as its language."iii

Being a natural unit, "the group becomes a single being, an individuality, a personality," in which culture is the national personality, the group mind. The bearers of this culture, and even more so the authors or creators of this culture, the "individual prophets, writers, artists or poets are but the means employed by the national soul to give expression to a national religion, a national language, or a national literature."iv Being natural and distinct, national culture and the nation should be cultivated, unfettered by artificial rules and undisturbed by other foreign influences; to do otherwise would be to upset nature's plan and to interfere with the natural processes of human development.

The relationship between early anthropology and the German philosophers like Herder (and Hegel and others) and ethnologists is a critical one for defining the concepts and the interests of the new field. German notions of Kultur and especially Kulturkreis are central in importance. Kultur, as Culture with a capital "c," is seen as one great world phenomenon, unfolding, developing, progressing in Hegelian fashion. In this way, all of the particular cultures of the world can be placed on the continuum of Culture. The German ethnologist Graebner and others interested in cultural history and evolution used the term Kulturkreis or "Culture circle" to refer to clusters of cultural traits which existed at various places at various times and distinguished societies. The original culture circles were the goal of this study, and all of the world's cultures were to be classified in terms of their relation-their proximity or distance, geographically, temporally, and culturally-to the fundamental circles. The distribution of cultural traits thus became a central preoccupation of ethnology, along with the history of their diffusion. E.B. Tylor states that the geographical distribution and the diffusion of cultural traits must be studied in the same manner in which the botanist and the zoologist study plant and ani- 


\section{Ethnic Studies Review Volume 21}

mal species and their diffusion. It might even be argued that ethnology began as a kind of naturalist science, each "culture" or "society" viewed as a "species" distinguishable by a list of characteristics.

\section{The Critique of Race and Nationalism}

In a way, Franz Boas, perhaps the first professional modern anthropologist, both followed previous intellectual trends and set new ones. Furthermore, especially for our purposes, he saw anthropology as a vital contributor to important issues of the day such as racism and nationalism. He successfully and repeatedly deconstructed race as a concept, arguing that a race is not an objective or demonstrable descent group; there is as much physical variation within a race as between races; there are no "clear-cut geographical and biological lines between the races;"v and there is no correlation between race on the one hand and either mental or cultural characteristics on the other.

In his sociocultural analyses, Boas asserted that every "tribe" or "primitive society" is a closed society; even so, he recognized that primitive societies are not actually socially and culturally isolated, that even "the simplest groups" have been affected and changed by contact with each other. Every culture, then, is, in his view, constructed as much by external factors and influences as by internal ones. He also understood that, while social and racial phenomena are two discrete levels of reality and analysis, the two may overlap-"social divisions [may] follow racial lines"vi — and when they do the racial differences may be important for creating, preserving, and exacerbating social differences and inter-group conflict.

Boas also writes about nationalism in an instructive way. For example, he distinguishes between nation and nationality, using "nation" basically the way we would use "state" today and "nationality" basically as we would use "nation"; a nationality for him is "a group of people alike in speech, culture, and in most cases representing no fundamental racial contrasts." vii Yet, although nationalities are usually racially homogeneous, he granted "only the slightest relation" between nationality and race; in fact, he found most racial 
antipathies "fictitious" and actually derived from other sources than race, and in the final analysis he found both terms "vague." He saw no necessary equation between nations and nationalities. A nationality may inhabit two or more nations (he gives Italy before unification as an example), or two or more nationalities may inhabit the same nation (he gave Czechoslovakia and Poland as examples).

What exactly constitutes a nation, then? This is problematic: objective characteristics like descent or unity of language are not sufficient to make a solidary, identity-sharing group. Instead, it is something more subjective, more psychological or emotional-"the community of emotional life that arises from our everyday habits,...thoughts, feelings, and actions." "viii Where that community feeling is lacking, even individuals who share descent and language may not share identity and may actually be in conflict. But where nation-boundaries and nationality-boundaries are not co-terminous, social frictions may arise, eventually taking the form of nationalist movements.

Boas, interestingly, distinguished between two kinds of nationalism: the nationalism of nations and the nationalism of nationalities. Predictably, the nationalism of nations (what we might call "patriotism" today) attempts to unify the people of the nation regardless of the differences of constituent nationalities; it is integrative at the "state" or civil level. The nationalism of nationalities (modern "nationalism") strives to unify the people of the nationality regardless of nation (political) boundaries and is, therefore, disintegrative of actually-existing political organization and either separatist or "alternatively integrative" in the sense of positing a new political organization. Boas essentially applauded the efforts of nations and nationalities to integrate at a higher level, expressing "full sympathy" with their desire to dismantle "the artificial barriers of small political units."ix. However, he does not approve of nationalism in the sense of separatism and particularism, that is, of creating smaller and less inclusive social groupings. For him, inclusiveness, ever higher levels of social integration, ultimately a "federation of nations," is not only desirable but inevitable. He sees such an inexorable march toward integration in history (notwithstanding moments of revolution and devolution) that he is absolutely 


\section{Ethnic Studies Review Volume 21}

confident that this direction "will govern our history in the future" until its ultimate "consummation."x

\section{The Ethnography of a Changing Africa}

It was considered by early professional anthropologists "to be an advantage to be able to study those societies which are structurally so simple, and culturally so homogeneous, that they can be directly observed as wholes, before attempting to study complex civilized societies where this is not possible." Thus, for theoretical and political (i.e. colonialism) reasons, much of early anthropology's (especially British social anthropology's) attention was turned to Africa. However, even "functionalists" like Malinowski questioned this homogeneity and readily admitted the realities of cultural diversity, contact, and change. Often enough, what anthropology has to study is not the "uncontaminated' Native" nor the "well-defined, circumscribed entity" called "a society" or "a culture" of anthropological (and popular) imagination but a tumultuous social landscape in which each member and each society is part of a large, interconnected, constantly-changing whole which includes not only neighboring "natives" but Western societies and their agents and institutions as well. Therefore, even fifty years ago or more, he could maintain that "the scientific anthropologist must be the anthropologist of the changing Native. Why? Because what exists nowadays is not a primitive culture in isolation but one in contact and process of change."xii

Malinowski referred to nationalism as one of the "new and unexpected forces and factors" on the contemporary cultural scene. But two opinions are manifest in his investigation of non-Western (largely African) nationalism: that this nationalism is not a purely "native" phenomenon" and that it is not a purely "traditional" phenomenon. First, he perceived the role of Western culture, particularly but not exclusively in the form of colonialism and colonial administration, in the evolution or development of native nationalism. In cultural change, whether nationalism or some other type, there are generally "two cultures to deal with instead of one." New cultural phenomena and movements are a product of both cultural sources, but they are not a simple combination of the two old sources; rather, they 
are "entirely new products" born of the impact and hybridization of the two cultures, and the resultant phenomena have "no antecedents in Europe or in African tribalism." The nature, quality, and direction of a development such as native nationalism "is determined by factors and circumstances which cannot be assessed by the study of either culture alone.... The clash and interplay of the two cultures produce new things."xiii

Thus, nationalism, or we might add ethnicity, is certainly not a simple continuation of traditional culture into the modern political world. It is rather an emergent and original social phenomenon in itself. Even if it takes the form of revivalism or irredentism or millenialism or what have you-even if it refers to or invokes tradition or culture or history-it is not "tradition" but some new treatment of and perspective on tradition. Such nationalism or ethnicity is precisely "retrospective" in the sense that it is not tradition but a memory of or a look back at a culture and custom which once was-or maybe never was. The former "tribalism" and the contemporary "nationalism" are anything but identical for Malinowski: tribalism is un-self-conscious, while the new nationalism is sophisticated and self-conscious, reaching for "elements of the old culture....with a secondary, almost ethnographic interest in racial history, customary law, and the artistic and intellectual achievements of their race."xiv The old tribalism is already dead, and what is afoot at present is not a memory but an invention.

Accordingly, the objective establishment by anthropological means of the "true culture" or the "true past" of a society is in the end less important, not only in itself but for understanding contemporary activities, than the study of what is going on presently and how that culture and past is being employed and deployed in the present. In true functionalist fashion, he argued that what anthropologists are often eager to collect (that is, what the "old men of the tribe" have to tell us about the past, the "authentic culture," etc.) is less than useless as science, as scientific investigation of the past, since it is memory, "affected by sentiment, by retrospective regrets, and longings." However, in a particularly insightful moment, Malinowski suggested that this is not only all right but important-important for understanding not the past but the present-since for the modern anthropologist studying cultural 


\section{Ethnic Studies Review Volume 21}

change, "what really matters is not the objectively true past, scientifically reconstructed and all-important to the antiquarian, but the psychological reality of today."xv Therefore, he allows us to see that native nationalism, even in its early manifestations, is not "traditional culture at work" but "traditional culture remembered," and that the "retrospective vision" upon which it is based is subjective and, ultimately, creative.

Fortes and Evans-Pritchard provide an analysis of several specific "traditional" African societies and find that they are neither so traditional nor always "societies" in the strictest sense. They describe, for example, that supposedly homogeneous African societies actually exhibit a striking amount of heterogeneity. In the introduction, they state that groups such as the Zulu, Ngwato, Bemba, Banyankole, and Kede "appear to be an amalgam of different peoples, each aware of its unique origin and history, and all except the Zulu and Bamba are still to-day [sic] culturally heterogeneous."xvi The contributions which make up the book support this general contention, adding that the groups themselves and the territories they occupy are often fairly recent developments. The Zulu, for one, were only constituted as a "nation" when the defeated peoples of the great leader Shaka were organized into a single politicalcultural complex; within the "nation" "old tribal loyalties and oppositions are still at work and faction fights frequently occur."xvii Schapera describes how the Ngwato "tribe" is a congeries of people, with about $20 \%$ actually belonging to the "nuclear community" of Ngwato (and even they were aggregated only in the eighteenth century after a schism from the Kwena group) and the rest coming from diverse populations "who became subject to the Ngwato chiefs at various times through conquest in war, voluntary submission, flight from an invading enemy, or secession from some other tribe."xviii Richards reports that many of the "traditional societies" of Africa have occupied their territory for less than two hundred years and many for as little as fifty to one hundred.

Finally, Gluckman argues that not only is diversity within "traditional societies" ordinary and tolerable but that conflict is also ordinary and may even be integrative. Societies, even small traditional societies, are "always elaborately divided...by customary allegiances" which cross-cut and sometimes con- 
tradict and come into conflict with each other. The central point of his book is to show "how men quarrel in terms of certain of their customary allegiances, but are restrained from violence through other conflicting allegiances which are also enjoined on them by custom."xix Thus, it becomes possible to think of societies as internally diverse and segmented while still integrated; at the same time, it becomes clear that societies may not be as integrated as ethnic or national ideology and action stipulate or require. Finally, the crucial lesson for us in regard to modern ethnicity and ethnic conflict, as Gluckman's analysis shows, lies in the cross-cutting allegiances which "tend to inhibit the development of open quarrelling" and worse in the totalizing, and thus segregating, ideology. In contemporary ethnicity, some or all of these cross-cutting and therefore unifying institutions or customs are lost or denied. The totalization of "culture" and of the claims based on culture let slip the restraints which bind groups in civil, if hostile, relations and create conditions for uninhibited and total confrontation and conflict.

\section{Plural Societies and Fluid Boundaries}

The great early ethnographers tended to represent traditional societies as discrete units in general isolation from other groups and from outside influences, especially Western influence (even when, as we have seen, their own commentary contradicted this image). Two works in the 1950s began to challenge that view, both theoretically and ethnographically. One of these is Furnivall's Colonial Policy and Practice $x x$ which is noteworthy for its acknowledgment of the inextricable link between traditional-societies-as-found and colonial and other outside factors and for the elaboration of the concept of "plural society." The book offers two consequential insights: that colonial societies (particularly Burma and Netherlands India or Java) are heterogeneous and that nationalism in the two societies is a result of colonialism. Burma, for example, is not one society but many; Burmese (or Burmans, as a "national" or "ethnic" category) are one of numerous peoples (which he calls "races") in the territory including Shan, Mon, Karen, Kachin, etc. "Burmese society" as a modern social system also con- 


\section{Ethnic Studies Review Volume 21}

tains other important groups, the exclusion of which from analysis would illicitly simplify or even falsify the picture. These other groups include Indians, Chinese, and of course Europeans. Not only was this society heterogeneous, but it was also "enclaved," with Indians, Chinese, Europeans, and "Burmese" all filling different "niches" in the social system (with the Chinese and Indians monopolizing the "middleman" positions of finance and trade between Europeans and the general population). These groups formed what we would only call today "ethnic groups" and differed considerably in their interests. These differences resulted in communal violence in 1924 and 1931.

In Burma he sees nationalism at its earliest in the area of religion, on the part of Buddhist monks who organized religious revivalist movements and institutions such as the Young Men's Buddhist Association. Nationalism at this stage took the form of interest in the past culture of Burma-or one of the past cultures of Burma. By 1921, though, he reports that nationalism had passed from religious to political expression, and the new General Council of Buddhist Associations set its goal as home rule or even complete separation from England. The divergent interests of the constituent communities, coupled with the low mobilization of the masses, made concerted action difficult. There was, in effect, no "Burmese nation" from which a movement could arise and for which it could speak. The consequences of self-government have been profound. As a first step, a Burma Government was established under the British Parliament in 1937 but showed a number of weaknesses. For one thing, the legislature had authority only over Burmese people and not others in areas traditionally and administratively associated with Burma, such as Karenni, the Kachin Hills, or the Shan states. For another, the legislative seats were allotted on two different principles, territory and community. Just under a third of the seats (40 out of 132) in the House of Representatives were reserved for communal or other special interests, 37 of those 40 for Karens, Indians, Chinese, and naturally Europeans. Thus, representative government actually did not help integrate the society but rather set the stage for the activation, aggravation, and escalation of "sectional friction"(487). Placing groups in a position to com- 
pete for political power as groups threatened to elevate cultural and economic differences into political and "nationalistic" level.

The other element in Furnivall's analysis, and by far the more enduring one, is his concept of the plural society. Politically, a plural society "comprises separate racial sections" (or again, we might prefer "ethnic" over "racial," although in the case of Burma the differences are more than just cultural). There is a mix of different groups, each with its own culture, language, religion, etc., but more crucial than their co-presence is their social segregation: "they mix but do not combine"(304). They live side-by-side as citizens of the same polity but do not form a society in any significant way; they constitute a sort of caste system without the religious integration of the real thing. This is why Furnivall rejects the characterization of the U.S. and Canada as plural societies: they have "plural features" (that is, a diversity of cultures and races sharing political and economic space), but they also have at least some measure or ideology of integration and equality.

An even more influential early ethnography for the purpose of elucidating ethnicity and the relation between ethnic groups and culture also took place in Burma. Leach's Political Systems of Highland Burma xxi was the first serious and successful challenge to the standard approach of anthropology toward "society" and "social boundaries" up to that time. Encountering an extremely diverse and tangled cultural situation in the area of fieldwork, the Kachin Hills Area, he found that it was impossible to maintain simple and consistent distinctions or boundaries between the "social groups."

The two main social categories in the region are Shan and Kachin. Shan are Buddhist, wet-rice cultivators, and organized into hierarchical "castes" with a hereditary nobility. Kachin, on the other hand, are an assortment of "hill peoples" with significant differences in language, territory, and politics from each other. Thus, here began Leach's problem. First, there was no systematic relation between the linguistic, the territorial, and the political aspects of Kachin groups; it was difficult to determine where one group ends and the next begins, or even whether they are "different groups" at all. Second, transfer of population, individually and collectively, is possible 


\section{Ethnic Studies Review Volume 21}

between Kachin and Shan categories; Shan society has been assimilating Kachins for at least a century (and probably much longer), such that "nearly all low class Shans are probably either of slave or commoner Kachin origin"(222). And the overall oscillation between political structures which he found within Kachin societies was also a result of association with and imitation of Shan politics: Kachin chiefs took Shan princes as their role-models and attempt to emulate their powers and prerogatives.

From these observations Leach asked the question which naturally occurs to us today but which he was perhaps the first one to perceive: When can we say that two groups are "two different societies" or merely "two segments of the same society"? The failure to tackle or even recognize this problem anthropologically up to this point, he argues, is in the very anthropological concepts of "society" and "culture"; in such complex and enmeshed social contexts as highlands Burma, "ordinary ethnographic conventions...are hopelessly inappropriate"(281). In fact, he maintains that the differentiation of Shan and Kachin as distinct "societies" was an invention of British colonial administration in Burma, which imported Western notions of discrete social units and even more so of race. The entire population was classified for administrative purposes by race-race, he finds, "being a synonym for language.... The Kachins were deemed to be a 'race' therefore they must possess a special language"(43). Further, the British tried to draw clear territorial boundaries between the "Shan" and "Kachin" "societies." Where language/dialect and territory coincided, especially if some order of kinship relation could be established for the "enclosed" group, a "tribe" was inferred.

Leach's answer to this situation is to reconceive the units of analysis in anthropology and the reasons for cultural variation. "Tribe" is, at least in many cases, an "academic fiction": "the ethnographer has often only managed to discern the existence of 'a tribe' because he took it as axiomatic that this kind of cultural entity must exist" (291). Rather, he suggests a unit of analysis appropriate to the ethnographic context, which in the present case would be the entire Kachin Hills Area with its many cultures, languages, and named collectivities. Such 
collectivities would not be considered "social isolates" but elements in a larger and more inclusive social system. Second, the collectivities which comprise the system, and indeed the system itself, should be seen to have no stability through time: individuals flow from one political system to another; entire villages or groups undergo structural transformation from one political system to another, and the very form of the over-arching system may change as time proceeds. The traditional anthropological notion of equilibrium in society is rejected by Leach.

Thus, in the end, Leach concludes that cultural categories and cultural identities are not really objective, tangible things but subjective, symbolic things; the identity or boundary of a social collectivity "is not necessarily ascertainable in the realm of empirical facts; it is a question, in part at any rate, of the attitudes and ideas of particular individuals at a particular time"(288). In reconceiving "culture" and "society" as so open, fluid, even invented, the relationship between the two becomes for us analysts and ethnographers much more problematic, various, and unique to each case.

\section{Primordialism: Natural Bonds to Cultural Givens}

Within a decade, Old Societies and New States, xxii appeared and shaped subsequent discourse, not only within anthropology but within ethnic studies. A number of authors contributed to this volume, but by far the most influential chapter is the one written by Geertz himself, "The Integrative Revolution: Primordial Sentiments and Civil Politics in the New States." The book grows out of and adds to the increasing awareness among anthropologists of the cultural consequences and problems of the "new states" formed as a result of decolonization; while this topic is compelling enough in itself, it also has implications for the typical "objects" of the discipline, the "traditional," small-scale social isolate called a "society" or "culture." With the new "nation-building," the so-called "integrative revolution," these social units are no longer isolated and self-contained but become part of larger, more inclusive social 
systems. Anthropology's method and concepts would have to adjust accordingly as the objects of study themselves or perhaps even disappear.

Geertz, following Edward Shils, sees the problem of the new states as stemming from the "primordial" diversity of the enclosed societies within the states, which resists or at least complicates the creation of a state-wide society or "civil order." In a word, "the new states are abnormally susceptible to serious disaffection based on primordial attachments"(259). He goes on to explain his notion of "primordial" and "primordial attachment" in one of the most oft-quoted passages in all of anthropology or ethnic studies:

By primordial attachment is meant one that stems from the "givens"-or, more precisely, as culture is inevitably involved in such matters, the assumed "givens"-of social existence: immediate contiguity and kin connection mainly but beyond them the givenness that stems from being born into a particular religious community, speaking a particular language, or even a dialect of a language, and following particular social practices. These congruities of blood, speech, custom, and so on, are seen to have an ineffable, and at times overpowering, coerciveness in and of themselves. One is bound to one's kinsmen, one's neighbor, one's fellow believer, ipso facto, as the result not merely of personal affection, practical necessity, common interest, or incurred obligation but at least in great part by virtue of some unaccountable absolute import attributed to the very tie itself $(259-60)$.

The political problem, as he sees it, is that this primordial particularism-"tribalism, parochialism, communalism, and so on"-threatens civil order and state integration in a more aggressive and insatiable way than other forms of social identity or discontent. "Economic or class or intellectual disaffection threatens revolution," but primordial disaffection threatens the boundaries if not the very existence of the state; it rejects outright the whole idea and fact of the state and its disembodied civil order outright. For this reason primordial sentiments have "a more ominous and deeply threatening quality than most of the other...problems the new states face"(261). 


\section{Circumstantialism: Ethnic Boundaries, Not Ethnic Contents}

There were always those in anthropology and elsewhere, like the Marxists, who rejected the primordial argument and favored a constructionist or "circumstantialist" approach. The seminal book within anthropology for this position was Ethnic Groups and Boundaries xxiii by Barth and his contributors. Like Leach before them, they find that cultural variation and social/ethnic boundaries are not co-terminous: groups with qualitative cultural differences are often subsumed under the same social/ethnic label and identity by outsiders or even by members, while groups with no major cultural differences are often distinguished into two or more social/ethnic categories. Consequently, "although ethnic categories take cultural differences into account, we can assume no simple one-to-one correspondence between ethnic units and cultural similarities and differences"(14). Failing to find any sure understanding of ethnicity through a description of the content of a culture, Barth directs our attention instead to the relations between groups and the ways culture is used to generate and preserve those relations.

The two central notions of this approach are ethnic boundary and social interaction. Ethnic groups are categories or categorial distinctions, socially bounded groups as determined by the social conditions in which two or more groups live and interact (even if that interaction takes the form of no interaction, as in total communal segregation). Ethnic groups are thus understood "as a form of social organization," a particular species of social categorization which "classifies a person in terms of his basic, most general identity, presumptively determined by his origin and background"(13). One of the curious and problematic things which he and his colleagues, and many other anthropologists, have noticed, though, is that social identity is not entirely ascribed, that people can in fact change their identity and their social/ethnic affiliation in many cases (although not always or in any way). In the book under discussion, fur farmers in Africa, for example, can become Baggara pastoralists. What is interesting to Barth and the rest is that, although personnel may flow from one category or group to 


\section{Ethnic Studies Review Volume 21}

another, the boundaries of the categories or groups persist. In fact, in this view, the continuity of ethnic groups depends neither on biological nor cultural continuity; individuals may come and go, and cultural traits may come and go. On the contrary, the "continuity of ethnic groups...depends on the maintenance of a boundary. The cultural features that signal the boundary may change, and the cultural characteristics of the members may likewise be transformed; indeed; even the organizational form of the group may change, yet the fact of continuing dichotomization between member and outsiders" can remain (14). Simply stated, it is "the ethnic boundary that defines the group, not the cultural stuff that it encloses"(15).

The ethnic-boundary approach allows-or forces-us to consider how ethnic distinctions emerge. Barth proposes that there is no obvious or a priori way in which ethnic groups are formed or in which culture is deployed in the formation; indeed, only circumstances will determine which cultural traits "are used... as signals and emblems of difference," which "are ignored," and which "are played down or denied"(p.14). Any number of elements-"tribe, caste, language group, region or state," to which we might add religion, history, race, custom, and others-are perfectly adequate and useful as ethnic "diacritica." Additional consequences to mention in this diminution of the role of cultural difference in ethnic identities would be that the loss of difference between groups, assimilation in the purest sense, would not necessarily lead to a reduction in the personal salience or the "organizational relevance" of ethnic identity and that a great knowledge of culture, in particular of the history of culture-of culture in the past, of "tradition"would not necessarily lead us to a greater knowledge or understanding of the ethnic group.

\section{Constructing Culture and Rethinking Anthropology}

Barth's and other studies emphasize creativity and adaptability over tradition and the "survival" of primordial factors. In particular, changes in the subject-matter of anthropological inquiry (ostensibly, "primitive" or "traditional" societies) began to raise epistemological concerns within anthropology itself. These changes include the emergence of new social groups, "super- 
tribalization" or the formation of larger social units through amalgamation or absorption of smaller ones, culture-based (i.e. indigenous rights or irredentist) social movements, cultural revivals, etc., state-building processes and cultural resistance to these processes (including nationalist and separatist movements and ethnic wars), "tribally" organized resistance to development projects such as the Kayapo anti-dam activities in Brazil, and the "nativization" or rejection of post-colonial Western culture and/or the reclamation of (sometimes defunct) traditional cultural features. We might also mention the entry of "tribal peoples" into professional and political positions, with advances in their education which gave them access to anthropological writings. Altogether, these factors raised the unavoidable issue of inter-society contact and extra-society connections, rendering the concept of isolated and static societies utterly obsolete. They helped precipitate an epistemological crisis in anthropology: who exactly is the Other? How can we describe them in ethnographic terms? How can our methodologies cope with the interconnected complexity of the emerging social order? In the end, is knowledge of other cultures possible, and if so, what responsibilities and guilts do we bear as members (and representatives) of dominant, formerly colonial societies?

Among the first to respond was Hymes, with three issues of importance to ethnicity. The first of these revolves around the concept of culture as "traditional" versus "emergent." If the objects of study are changing, then the study too must change: anthropology should, Hymes states, redefine itself from the study of primitive or small-scale societies to "the study of the emergence of cultural forms in concrete settings and in relation to a world society."xxiv The second issue concerns the role of anthropology in particular and of Western society in general in the political, that is exploitative, relations between "our" society and "the Others." William Willis, one of the contributors, defines anthropology as, to a large extent, "the social science that studies dominated colored peoplesand their ancestors-living outside the boundaries of modern white society." $x \times v$ Therefore, anthropology has been anything but a pure scientific endeavor; even the concepts and theories of anthropology he sees as having political ramifications: ideas 


\section{Ethnic Studies Review Volume 21}

of primitive society, of isolated society, of functionalism, of ethnographic voice at work to "absolve white people of their crimes" against colored societies, to "facilitate the imperial policy of divide and rule," and to "preclude the discovery of sociocultural links wider than tribal allegiances." xxvi

The third issue from Hymes' book is the specifically epistemological one-whether our ethnographic descriptions are objective accounts of other cultures. Berreman quotes Zaretsky's criticism of the positivist ethnographic tradition "that the truth is there and that it is objectively discoverable, if only we experts look hard enough; if only we find the right models."xxvii Scholte takes a clear stand in asserting that anthropology "is never only scientific" and that, "as cultural products and processes" themselves, anthropology's concepts, methods, and "knowledge" are bounded by the culture and interests of anthropologists, making anthropology itself an appropriate object of investigation to anthropology.

Wagner takes this analysis one step further, considering how anthropology actually invents culture, in two senses: as the general idea of culture and as the particular individual social units or cultures to be described. This invention consists of the assumption and then the construction of "a concrete entity, a 'thing' that has rules, 'works' in a certain way, and can be learned"xxviii; that is, as the anthropologist tries to account for, understand, and represent the behavior of others, he/she creates a cultural "object' out of the data and experience. Anthropology, in this interpretation, is "the study of man 'as if' there were culture"(10). "The study of culture is in fact our culture" (16). He even likens anthropology to a culture-cult.

Having allowed this kind of creativity to anthropologists, he says, we cannot deny the same kind and import of creativity to the culture itself and its members. He goes so far as to suggest that invention is culture. The implication of this perspective is that all people-anthropologists and natives, "modern" or "traditional"- - are creatively assembling and advancing their behavior, the reasons for their behavior, and the circumstances (or interpretations of circumstances) of their behavior continuously, especially under conditions of social ambiguity or novelty which provide a kind of culture shock; people control 
and make sense of their experience "through all kinds of imagined and constructed 'rules,' traditions, and facts" (35).

Since then others have continued to develop and build upon these insights with important consequences both for anthropology and for ethnicity studies. Hobsbawm and Ranger, for instance, present data to show that many phenomena which we call traditional are in actuality relatively new, that behaviors or symbols "which appear or claim to be old are often quite recent in origin and sometimes invented."xxix Such "invented traditions" refer to the past and avow a continuity with the past, but this continuity is "largely factitious," serving an ideological function as "a legitimator of action and cement of group cohesion." The invocation of the past, the establishment of a link to the past, gives ethnic groups and nations what they need most-an apparent continuity and naturalness or primordiality. In fact, they assert, as others have, that "tradition" of this sort is evidence of a distinct and decisive break with the past, a new self-consciousness, reflexitivity, and problematicization of culture and identity which would be odd if not impossible in the "traditional" setting to which invented traditions refer: after all, "when the old ways are alive, traditions need be neither revived nor invented"(8).

Anderson goes even further to consider nations as "imagined communities" in which the members "will never know most of their fellow-members, meet them, or even hear of them, yet in the minds of each lives the image of their communion." $x \times x$ The crucial features of this image of nation are its boundedness, its sovereignty, and its community (that although there are social differences and inequalities-vertical differences-within the nation yet the nation shares a "deep, horizontal comradeship"). In particular, the development and diffusion of printing and vernacular print-languages created "unified fields of exchange and communications" giving rise simultaneously to a culture, an audience for that culture, and the mental image of that audience as a community to its far-flung members. In print but not only in print, for also in other mass media like radio and television, as well as in political activity (the formation of parties, the giving of speeches, the casting of votes, etc.) and many other practical behaviors, a disparate group can 


\section{Ethnic Studies Review Volume 21}

come to recognize or believe in commonalities with each other, whether or not those commonalities are old or even real.

Kuper picks up one thread of this argument to show that a particular kind of culture, or a particular conception of culture, is invented, that is, "primitive" culture. He demonstrates, through a consideration of the early history of anthropology, how the idea of primitive society was "a fantasy which had been constructed by speculative lawyers in the late nineteenth century"xxxi such as Bachofen, Maine, McLennan, and Morgan (8). Indeed, the "idea of primitive society fed the common belief that societies were based either on blood or on soil and that these principles of descent and territoriality may be equated with race and citizenship, the contrasting components of every imperialism and every nationalism"(9). Yet, even as he says this he perceives that anthropology is changing-perhaps again, reinventing itself. "It is no longer about the primitive, and no longer particularly or necessarily about 'the Other"'(243).

In fact, the object of anthropological inquiry is often these days anthropology itself. This is most forcefully posited in Clifford and Marcus. In Clifford's introduction, he asserts that ethnography, the central activity of knowing and describing culture in anthropology, "is always caught up in the invention, not the representation, of culture."xxxii Our knowledge of other cultures is not entirely scientific or "objective" because it is partial and perspectival, constructed in the encounter between anthropologist and member, and conditioned by all sorts of anthropological customs and conventions. In fact, such knowledge could not be scientific or objective since cultures "are not scientific 'objects'...[but] are produced historically, and are actively contested"(18). In particular, the notion of anthropological literature is taken very seriously, alluding to all of the literary devices and tropes that ethnographers employ to represent the knowledge or experience they gain in the field and to present that knowledge and experience, from narrative voice to scene-setting techniques to the dissolution of the investigator into the "objective" account of the culture. Description is implicated with representation (choices about how to make the culture-as-learned-by-the-ethnographer at once clear, convincing, compelling, and relevant) as well as interpretation and, in the end, invention by both researcher and informant; the informant 
"invents" answers to specific questions, and the researcher "invents" a coherent monograph and therefore "culture" out of the answers. Thus, Clifford identifies what he calls the "cultural poesis" which is located in the "specific exclusions, conventions, and discursive practices" of ethnography.

The consequences for ethnicity of the poetic and political invention of culture should be obvious. Fischer, explicitly states that ethnicity, like all other facets of culture, "is something reinvented and reinterpreted in each generation by each individual,"xxxiii even if it may seem natural, incomprehensible, or individual him/herself. As an invention it can never be mere or pure tradition but is a contemporary product of "a process of inter-reference between two or more cultural traditions," particularly the "ethnic" culture and the modern plural culture in which it is currently situated and for which it is currently prepared. Therefore, as we have seen repeatedly, ethnicity may evoke a past to which it is connected-and it may even actually be connected to that past-but the real point of ethnicity, Fischer writes, is to create new values, a new vision of meaning and "the good," "an ethic workable for the future."

\section{Conclusion: The Message of Culture-and the Messenger}

The anthropologist is a messenger, yet he or she is a not mere and objective messenger: when one finds a message (the "culture" or may even more so the "meaning" of the culture) "he appropriates it, translates it, and makes it 'relevant' to those to whom he delivers it."xxxiv In a certain sense, anthropology creates or styles its message and meaning out of its encounter with particular people and social situations. The anthropologist does not, in the end, merely discover a society or culture nor "translate" cultural "texts" "the way the translator does. He must first produce them"(43).

The implication for ethnicity in simply this: if, upon reflection, we can identify and attribute these facets and forces to the anthropological "version" of culture, we can hardly deny them to the "native's" or "member's" version. In other words, as members go about "doing" their culture they are also creating their culture, out of the same "complex play of desire and power" which is heightened and focused in the ethnographic 


\section{Ethnic Studies Review Volume 21}

encounter. "Culture" and "history" exist as a kind of passive and plastic data which individuals, groups, and proto-groups and would-be groups can interpret, consciously or unconsciously, and even manipulate in the service of their desire and power. Desire-to be a group, to be a superior group, to right perceived wrongs, to establish a culture-based society or polity, or what have you-can color the "facts" or "truths" of "culture" so thoroughly that the desire becomes the truth; in a more sinister manner, if an individual, party, or group desires to achieve power or status by way of culture, by invoking culture and calling upon others to heed the call, it is all too easily done. In the process, the messenger takes on a second role as message-creator, although he or she may mystify this role by claiming merely to "find" or "discover" or "recognize" or "represent" a true culture out there. At the same time, message receiver, the "group-out-there," which may not have been waiting for a message, has its own desires, which may or may not coincide with those of the messenger-or may be made to coincide.

In a sense, then, the ethnic leader or "ethnic entrepreneur" $x x \times v$ not only carries a cultural "truth" but invents one, especially when the ethnic group is not fully "self-aware" or "awake" until the leader and his truth appear. This is why we so often find competing leaders with competing messages about what the group is, which part of its culture or history is most critical to its identity and future, and what it should do next. Ethnic members, like anthropologists, are free to look for their message, to let their desire lead them toward certain messages, and to act upon the message which compels or serves them; different members will necessarily find and convey different messages from the same culture and history, and the "ethnicity" which ultimately emerges can only be understood as a consequence of "the complex play of desire and power" between the competing versions and their competing carriers.

In conclusion, we have followed the development of the concept of ethnicity and ethnic group in anthropological theory and ethnography from that of a natural and primordial, almost physical and spiritual, phenomenon to a problematic and variably-bounded one to, ultimately, a constructed, political, poetic, and future-oriented one. We have seen that this development has been driven principally by changes in the phenomenon 
itself-the rise of new groups, the demise of old groups, the shift of cultural foci of existing groups, and the emergence of political significance for ethnicity. Anthropology, as the science of culture, has helped problematize culture in a valuable way for ethnic studies. Simply put, ethnicity is not identical to culture or tradition, and ethnic groups are not necessarily distinct cultural groups. It has become clear that we cannot get at ethnicity merely by way of "cultural content," of a list of cultural traits on which ethnic groups differ point by point. Groups in any common social system will share some traits and vary on others, and the ethnic lines do not always fall where the cultural lines do-and neither lines are permanent. In fact, an objective list of cultural traits does not even exist in a certain sense but is constructed, invented, in social interaction, whether this interaction is the fieldwork encounter, the colonial encounter, or the contemporary ethnic members' experience in his or her plural society. While ethnicity and ethnic conflict are not mere or pure cultural opportunism, and invention (of groups or even of traits) is not completely without restraint, failure to recognize the contextual, circumstantial, fictive, and political qualities of ethnicity render it and its resultant manifestations much more opaque, irrational, and absolute than they really are.

\section{NOTES}

i E.E. Evans-Pritchard, Social Anthropology (Glencoe, IL: The Free Press, 1951), 4.

ii Robert Reinhold Ergang, Herder and the Foundations of German Nationalism (New York: Columbia University Press, 1931), 95.

iii Ergang, 88.

iv Ergang, 87. 
Ethnic Studies Review Volume 21

$\checkmark$ Franz Boas, Anthropology and Modern Life (New York: W.W. Norton \& Company, Inc., 1928), 29.

vi Boas, 74 .

vii Boas, 78.

viii Boas, 89 .

ix Boas, 91.

$x$ Boas, 98.

xi Evans-Pritchard, 8-9.

xii Evans-Pritchard, 12.

xiii Evans-Pritchard, 25.

xiv Evans-Pritchard, 158.

XV Evans-Pritchard, 29.

xvi Meyer Fortes and E.E. Evans-Pritchard, eds., African Political Systems (London: Oxford University Press, 1940), 9.

xvii Max Gluckman, "The Kingdom of the Zulu in South Africa," in African Political Systems, 51.

xviii Gluckman, 57.

xix Max Gluckman, Custom and Conflict in Africa (Oxford: Basil Blackwell, 1956), 2. 
xx J.S. Furnivall, Colonial Policy and Practice: $A$ Comparative Study of Burma and Netherlands India (New York: New York University Press, 1956)

xxi Edmund Leach, Political Systems of Highland Burma (Boston: Beacon Press, 1954)

xxii Clifford Geertz, ed., Old Societies and New States: The Quest for Modernity in Asia and Africa (New York: The Free Press, 1963)

xxiii Fredrik Barth, ed., Ethnic Groups and Boundaries (Boston: Little, Brown \& Co., 1969)

xxiv Dell Hymes, ed., Reinventing Anthropology (New York: Random House, Inc.,), 35.

$x x v$ William Willis, Jr., "Skeleton in the Anthropological Closet," in Reinventing Anthropology, 123.

xxvi Willis, 143.

xxvii Hymes, 93.

xxviii Roy Wagner, The Invention of Culture (Englewood Cliffs, NJ: Prentice Hall, Inc., 1972), 8.

xxix Eric Hobsbawm and Terence Ranger, eds., The Invention of Tradition (Cambridge: Cambridge University Press, 1983), 1.

xxx Benedict Anderson, Imagined Communities: 
Ethnic Studies Review Volume 21

Reflections of the Origin and Spread of Nationalism (London: Verso), 15.

xxxi Adam Kuper, The Invention of Primitive Society: Transformation of an Illusion (London: Routledge, 1988)

xxxii James Clifford and George Marcus, eds. Writing Culture: The Poetics and Politics of Ethnography (Berkeley: University of California Press, 186), 2.

xxxiii Michael Fischer, "Ethnicity and the Post-Modern Arts of Memory," in Writing Culture: Poetics and Politics of Ethnography, 196.

xxxiv Vincent Carapanzano, Hermes' Dilemma and Hamlet's Desire: On the Epistemology of Interpretation (Cambridge: Harvard University Press, 1992), 3.

xxxv Nelson Kasfir, Explaining Ethnic Political Participation," World Politics 31 (1979):365-88.

Jack Eller, Ph.D. teaches at Westwood College of Technology in Denver, Colorado. 